\title{
Toward a framework of muscularity-oriented disordered eating
}

\author{
Scott Griffiths ${ }^{1 *}$, Stuart Murray ${ }^{2}$, Stephen Touyz ${ }^{1}$ \\ From 2013 ANZAED Conference: Inspiring Change: Person and Context \\ Melbourne, Australia. 23-24 August 2013
}

Sociocultural forces promoting a thin ideal body for women have shaped our understanding of problematic eating attitudes and behaviours throughout the 20th century, giving rise to the modern, thinness-oriented definition of disordered eating. More recent cultural expectations of a lean and muscular body, particularly for males, have been named as likely contributors to the growing prevalence of muscularity-focused body image disturbance amongst boys and men. However, disordered eating in the pursuit of muscularity appears in stark contrast to that which is motivated by the drive for thinness, suggesting that a new disordered eating framework specific to muscularity is needed. We define muscularityoriented disordered eating and propose a framework constituting five major components, including body image concerns, eating, nutritional supplements, appearance and performance enhancing drugs, and exercise. We critically analyse the nature, prevalence and effects of these facets of muscularity-oriented disordered eating, and suggest improvements and directions for future research. Intentions of this framework are to inform clinicians engaged in the treatment of muscularity-related body image and eating disturbance, and to guide future empirical research and interventions in this field.

This abstract was presented in the Body Image stream of the 2013 ANZAED Conference.

\section{Authors' details}

${ }^{1}$ University of Sydney, Australia. ${ }^{2}$ Redleaf Practice, Australia.

Published: 14 November 2013

* Correspondence: scottgriffiths@gmail.com

'University of Sydney, Australia

Full list of author information is available at the end of the article
doi:10.1186/2050-2974-1-S1-050

Cite this article as: Griffiths et al:: Toward a framework of muscularityoriented disordered eating. Journal of Eating Disorders 2013 1(Suppl 1): 050.
Submit your next manuscript to BioMed Central and take full advantage of:

- Convenient online submission

- Thorough peer review

- No space constraints or color figure charges

- Immediate publication on acceptance

- Inclusion in PubMed, CAS, Scopus and Google Scholar

- Research which is freely available for redistribution
C Biomed Central

\section{Biomed Central}

